\title{
Leadership Competencies: The Contribution Of The Bachelor In Management And Leadership (BML) To The Development Of Leaders At First National Bank, South Africa
}

Sylvie Botha, University of the Free State, South Africa Madaleen Claassens, University of the Free State, South Africa

\begin{abstract}
The importance of effective managerial leadership is vital within the business environment. Business leaders, including those within the financial services industry, are confronted with numerous challenges. In order to deal effectively with those challenges, the unique developmental needs of business leaders need to be addressed continuously. From a South African perspective, business leaders are confronted with unique challenges such as globalisation, cultural diversity, black economic empowerment and transformation. Leaders whose competency levels are adequately developed are able to address these issues and succeed in adding value to their organisations. The question is whether the required leadership competencies can be acquired through tertiary education programmes that are specifically designed for adult learners, and whether this learning contributes to the growth of successful business leaders. This study focused on the leadership competencies required by leaders within the financial services industry exploring the contribution made by the Bachelor in Management and Leadership degree (offered by the University of the Free State in South Africa) to the development of leaders at First National Bank, a major financial services provider in South Africa. The results of the study indicated that the BML has indeed addressed the researched managerial leadership competencies utilised by First National Bank and that the programme has contributed significantly to the development and growth of its managerial leaders. However, certain gaps were identified and in order to ensure the sustainability of acquired knowledge and skills, it is recommended that a coaching and mentorship programme be introduced and implemented by First National Bank. It was also found that leadership in Africa faces unique challenges and it is foreseen that South African companies will place more emphasis on African leadership competencies in their leadership development programmes.
\end{abstract}

Keywords: Leadership competencies, managerial leaders, African leadership, competency behaviour, tertiary education, financial institutions, ubuntu.

\section{INTRODUCTION AND BACKGROUND}

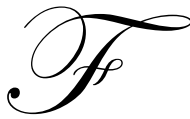

or businesses to be successful in a competitive business environment, they need to ensure that their leaders are well equipped with the necessary leadership skills. The development of leadership skills is a process whereby current and aspiring leaders learn the skills, competencies and behaviours required to be more effective.

Leadership development evolves in three ways, namely through experience, training and learning. The first 
two take place in the work place, while higher education institutions usually facilitate the latter. The School of Management at the University of the Free State and First National Bank (FNB) South Africa have been partnering with regards to the Bachelor in Management and Leadership degree (BML) since 2003. Initially the reason for introducing the BML was mainly to comply with the legislative requirements of the promulgated Employment Equity and Skills Development Act, as well as the Financial and Advisory Intermediary Services Act (FAIS) and to develop leaders who would contribute to the bank's leadership pipeline.

From a South African perspective, business leaders are confronted with numerous challenges, such as globalisation, cultural diversity, black economic empowerment and transformation. The business environment poses unique challenges that may require not only generic, but also inspirational and transformational leadership competencies. Given the political background of South Africa, numerous adaptations were necessary in the business environment since the first democratic elections in 1994. Khoza (2000) explains that a new concept of business in South Africa is required which should take into account the traditions and culture of the African participants in commerce and industry, i.e. the community concept. He explains that the community concept of management has a strong philosophical base in the concept of Ubuntu and brings to mind images of supportiveness, cooperation and solidarity. Nussbaum (2003) writes about Ubuntu as an African social philosophy and describes it as "the capacity in African culture to express compassion, reciprocity, dignity, harmony and humanity in the interests of building and maintaining community with justice and mutual caring". Ubuntu is a Nguni word from South Africa that calls upon us to believe that:

"Your pain is my pain

My wealth is your wealth

Your salvation is my salvation"

Booysen and Beaty (1997) also pointed out that the implications of an Ubuntu-oriented leadership style includes not only teamwork down to grass-roots level, but also the encouragement of team members or followers to sacrifice their personal gain or goals for those of the group as a whole. The authors indicate that this style includes creative cooperation, open communication, teamwork and reciprocal moral obligations.

The aim of this paper is to discuss to what extent the BML curriculum outcomes have met the expectations of First National Bank in South Africa in contributing to the development of its leaders. The first section of this paper is dedicated to a discussion of what leadership is, what are leadership competencies, also from an African perspective, and which of these form part of FNB's leadership competency framework. The content of the BML programme, its outcomes and stance on leadership competencies are also examined.

The second part of the paper focuses on the results of a survey that was conducted to determine whether the BML programme does indeed contribute to the personal development and growth in leadership competencies of the students, who are employed by First National Bank, and the majority of whom hold managerial leadership positions.

\section{LEADERSHIP COMPETENCIES}

Ulrich (2000) defines competencies as those behaviours that describe excellence in performance within a particular work context. A competency can be described as a set of behaviour patterns which an employee must display in order to effectively perform the tasks and functions of a designated role.

David McClelland conceived the original use of competencies. He first used competencies as an alternative for the replacement of intelligence tests with criterion reference testing (McClelland, 1973). He argued that intelligence tests were not valid predictors of intelligence, and thus irrelevant to the workforce. McClelland (1973) writes that competencies are normally based on an analysis by interviewing and observing an expert performer. During the analysis, key behavioural indicators are determined for successful performance of the job. These behavioural indicators are then linked to a competency.

According to Schlebusch and Roodt (2008) generic leadership competencies may be divided into defining sets, with specific dimensions. These are as follows: 


\begin{tabular}{|c|c|}
\hline \multicolumn{2}{|r|}{ Table 1: Generic leadership competencies } \\
\hline Competency set and dimensions & Definitions \\
\hline $\begin{array}{l}\text { Factor 1: } \\
\text { Leading and deciding }\end{array}$ & $\begin{array}{l}\text { Takes control and exercises leadership, initiates action, gives direction and takes } \\
\text { responsibility. }\end{array}$ \\
\hline $\begin{array}{l}\text { 1.1 Deciding on and initiating } \\
\text { action }\end{array}$ & $\begin{array}{l}\text { Making effective decisions (even in difficult circumstances), taking responsibility and } \\
\text { showing initiative. }\end{array}$ \\
\hline 1.2 Leading and supervising & $\begin{array}{l}\text { Providing others with clear direction, establishing standards of behaviour for others, } \\
\text { and motivating and empowering individuals. }\end{array}$ \\
\hline $\begin{array}{l}\text { Factor 2: } \\
\text { Supporting and cooperating }\end{array}$ & $\begin{array}{l}\text { Supports others and shows respect and positive regard for them in social } \\
\text { situations. }\end{array}$ \\
\hline 2.1 Working with people & $\begin{array}{l}\text { Demonstrating interest in others, working effectively in teams, building team spirit } \\
\text { and showing care and consideration for individuals. }\end{array}$ \\
\hline $\begin{array}{l}2.2 \text { Adhering to principles and } \\
\text { values }\end{array}$ & Upholding ethics and values, acting with integrity and promoting equal opportunities. \\
\hline $\begin{array}{l}\text { Factor 3: } \\
\text { Interacting and presenting }\end{array}$ & $\begin{array}{l}\text { Communicates and networks effectively relates to others in a confident and } \\
\text { relaxed manner. }\end{array}$ \\
\hline 3.1. Relating and networking & Establishing effective relationships with customers and staff. \\
\hline Persuading and influencing & $\begin{array}{l}\text { Making a strong impression on others, gaining agreement and commitment through } \\
\text { persuasion and negotiation and managing conflict. }\end{array}$ \\
\hline $\begin{array}{l}\text { 3.3. Presenting and communicating } \\
\text { information }\end{array}$ & $\begin{array}{l}\text { Speaking clearly and fluently, expressing opinions and arguments clearly and } \\
\text { convincingly and making presentations with confidence. }\end{array}$ \\
\hline $\begin{array}{l}\text { Factor 4: } \\
\text { Analysing and interpreting }\end{array}$ & $\begin{array}{l}\text { Shows evidence of clear analytical thinking. Gets to the heart of complex } \\
\text { problems and issues. Applies own expertise effectively. Communicates well in } \\
\text { writing. }\end{array}$ \\
\hline 4.1 Writing and reporting & $\begin{array}{l}\text { Writing clearly and succinctly in an interesting and convincing manner and } \\
\text { structuring information in a logical manner to facilitate the understanding of the } \\
\text { intended audience. }\end{array}$ \\
\hline $\begin{array}{l}\text { Applying expertise and } \\
\text { technology }\end{array}$ & $\begin{array}{l}\text { Applying specialist technical expertise, developing job knowledge and expertise, } \\
\text { sharing knowledge with others. }\end{array}$ \\
\hline 4.3 Analysing & $\begin{array}{l}\text { Analysing data of a verbal and numerical nature and other sources of information, } \\
\text { breaking information down into components, probing for further information and } \\
\text { generating workable solutions to problems. }\end{array}$ \\
\hline $\begin{array}{l}\text { Factor 5: } \\
\text { Creating and conceptualising }\end{array}$ & $\begin{array}{l}\text { Works well in situations requiring openness to new ideas and experiences. Seeks } \\
\text { out learning opportunities. Handles situations and problems with innovation and } \\
\text { creativity. Thinks broadly and strategically. Supports and drives organisational } \\
\text { change. }\end{array}$ \\
\hline 5.1 Learning and researching & $\begin{array}{l}\text { Learning new tasks quickly, remembering information and gathering data for effective } \\
\text { decision-making. }\end{array}$ \\
\hline Creating and innovating & $\begin{array}{l}\text { Producing new ideas and insights, creating innovative products and solutions and } \\
\text { seeking opportunities for organisational change and improvement. }\end{array}$ \\
\hline $\begin{array}{l}5.3 \text { Formulating strategies and } \\
\text { concepts }\end{array}$ & $\begin{array}{l}\text { Working strategically to attain organisational goals, developing strategies, and taking } \\
\text { into account a wide range of issues that impact on the organisation. }\end{array}$ \\
\hline $\begin{array}{l}\text { Factor 6: } \\
\text { Organising and executing }\end{array}$ & $\begin{array}{l}\text { Plans ahead and works in a systematic and organised way. Follows directions } \\
\text { and procedures. Focuses on customer satisfaction and delivers a quality service } \\
\text { or product to the agreed standards. }\end{array}$ \\
\hline 6.1 Planning and organising & $\begin{array}{l}\text { Setting clear objectives, planning activities well in advance, and managing time } \\
\text { effectively. }\end{array}$ \\
\hline $\begin{array}{l}\text { 6.2 Delivering results and meeting } \\
\text { customer expectations }\end{array}$ & $\begin{array}{l}\text { Focusing on customer needs and satisfaction, setting high standards for quality and } \\
\text { quantity and consistently achieving set goals. }\end{array}$ \\
\hline $\begin{array}{l}6.3 \text { Following instructions and } \\
\text { procedures. }\end{array}$ & $\begin{array}{l}\text { Following instructions and procedures, adhering to schedules, and demonstrating } \\
\text { commitment to the organisation. }\end{array}$ \\
\hline $\begin{array}{l}\text { Factor 7: } \\
\text { Adapting and coping }\end{array}$ & $\begin{array}{l}\text { Adapts and responds well to change. Manages pressure effectively and copes well } \\
\text { with setbacks. }\end{array}$ \\
\hline $\begin{array}{l}\text { 7.1 Adapting and responding to } \\
\text { change }\end{array}$ & $\begin{array}{l}\text { Adapting to changing circumstances, embracing change, being open to new ideas, and } \\
\text { dealing effectively with ambiguity. }\end{array}$ \\
\hline $\begin{array}{l}\text { 7.2 Coping with pressure and } \\
\text { setbacks }\end{array}$ & $\begin{array}{l}\text { Working productive in a stressful environment, controlling emotions in difficult } \\
\text { situations and handling criticism effectively. }\end{array}$ \\
\hline
\end{tabular}




\section{Leadership competencies at First National Bank}

Key business leadership competencies enable leaders to function at a highly competitive level. This section of the study examines what competencies and related behaviours First National Bank attaches to its different leadership roles.

In order to compile a list of leadership competencies most commonly used by First National Bank, the researcher examined the performance contracts and competency frameworks of the roles or positions occupied by individuals who may be designated as "leaders of others". The analysis revealed that from middle management (coordinator/team leader) to provincial leadership level, FNB attaches mostly generic competencies to the different management and leadership roles. Further analysis of the FNB competency frameworks revealed that the most commonly used competencies are the following:

\begin{tabular}{|l|l|l|}
\hline \multicolumn{2}{|c|}{ Competency } & \multicolumn{1}{|c|}{ Outcomes } \\
\hline 1 & Communication & $\begin{array}{l}\text { Presents ideas convincingly } \\
\text { Facilitates effective communication }\end{array}$ \\
\hline 2 & Passion for excellence & $\begin{array}{l}\text { Drives a passion for excellence } \\
\text { (eg. service, sales excellence) }\end{array}$ \\
\hline 3 & Performance management & $\begin{array}{l}\text { Takes ownership of own performance } \\
\text { Manages others' performance } \\
\text { Clarifies performance expectations with direct reports }\end{array}$ \\
\hline 4 & Teamwork and cooperation & Promotes a culture of teamwork \\
\hline 5 & Team development & $\begin{array}{l}\text { Establishes a culture of continuous learning and development (growth) of team } \\
\text { members }\end{array}$ \\
\hline 6 & Impact and influence & $\begin{array}{l}\text { Effectively influences others to reach agreement between parties and gain win- } \\
\text { win solutions }\end{array}$ \\
\hline 7 & Decision-making & Participative decision-making \\
\hline 8 & Customer relationship management & Drives customer relationship management \\
\hline 9 & Financial management & Drives financial performance of department / branch \\
\hline 10 & Coaching & Coaches team on achieving key result areas \\
\hline 11 & Change management & Drives the effective implementation of change initiatives \\
\hline 12 & Conflict management & Facilitates the resolution of conflict situations in the team \\
\hline 13 & Business acumen & $\begin{array}{l}\text { Understands the business of the organisation } \\
\text { Understands the local business environment }\end{array}$ \\
\hline 14 & Risk management & $\begin{array}{l}\text { Manages risk and compliance } \\
\text { Manages human resource risk to optimise team performance }\end{array}$ \\
\hline
\end{tabular}

\section{African leadership competencies}

Most leadership theories were developed over the last century and originated from the Western world. Key components referred to in the leadership theory are the leaders, the followers, and the situation or context. Both the leaders' actions and followers' responses reflect the forms of behaviour which are regarded as legitimate and appropriate within their particular society" (Shahin and Wright, 2004). Businesses in Africa, and particularly South Africa, are made up of multiple societies, with different cultural backgrounds and their leaders require unique and diverse competencies, in order to simultaneouly compete globally and to address the needs of their followers.

As discussed in the introduction to this paper, Khoza (2000) explains that businesses in South Africa should take into account the traditions and culture of the African participants in commerce and industry, i.e., the "community concept". This concept has a strong philosophical base in the concept of Ubuntu, which advocates values such as supportiveness, cooperation and solidarity. Van der Colff (2003) indicates further that African leadership is built on participation, responsibility and spiritual authority. 
Mgidi (2004) summarised key values in African leadership as follows:

1. Respect for the dignity of others;

2. Group solidarity: an injury to one is an injury to all;

3. Teamwork: none of us is greater than all of us;

4. Service to others in the spirit of harmony;

5. Interdependence; and

6. Persuasion.

The above characteristics or key values of African management have several similarities to generic leadership competencies such as teamwork, supporting and cooperating and impact and influence. Competencies that do not appear to receive enthusiastic attention from African leaders are performance management and accountability. Nkomo and Cook in Luiz (2006) assert that proponents of Ubuntu argue that while this approach emphasises teamwork and attention to relationships, it also asked for empathy between leader and followers. An over-emphasis on this empathy may stand in the way of effective performance management.

\section{Outcomes of the BML programme}

The BML programme is specifically designed for working adult learners in the field of management leadership. The overall outcome of the programme includes the integration of three domains, namely Management, Leadership and the Environment. From the listed programme outcomes it is evident that the majority of generic or core leadership competencies are addressed in the curriculum. On completion of the BML programme learners should be able to understand the role of the managerial leader in society with regard to human and economic development.

The BML programme is characterised by the emphasis on the need for the students to become critical and creative thinkers and ultimately develop into leaders who utilise innovative approaches in organisations. The following is a summary of leadership competencies which are addressed in the learning outcomes of some of the modules that are offered by the BML programme:

\begin{tabular}{|c|c|}
\hline \multicolumn{2}{|c|}{ Table 3: BML leadership competencies } \\
\hline Module & Competency \\
\hline Competency building & - $\quad$ Problem solving and effective time management \\
\hline Leadership skills & $\begin{array}{ll}\text { - } & \text { Act proactively } \\
\text { - } & \text { Begin with the end in mind } \\
\text { - } & \text { Put first things first } \\
\text { - } & \text { Think win/win } \\
\text { - } & \text { Seek first to understand and then to be understood } \\
\text { - } & \text { Manage differences effectively } \\
\text { - } & \text { Sharpen the saw }\end{array}$ \\
\hline General management & $\begin{array}{l}\text { - The role motivation plays in effective management through } \\
\text { applying various motivational approaches } \\
\text { - The control process as important management task }\end{array}$ \\
\hline Strategic marketing management & \begin{tabular}{ll|}
- & Cultivating strong customer relationships \\
- & Understanding the competition \\
\end{tabular} \\
\hline Strategic management & $\begin{array}{l}\text { - Understand the importance of different organisational } \\
\text { settings in terms of strategic management }\end{array}$ \\
\hline On becoming a creative thinker and decision-maker & - $\quad$ The decision-making process \\
\hline Confronting change, stress and time & $\begin{array}{ll} & \text { Ability to manage change } \\
- & \text { Stress management } \\
\text { - } & \text { Effective time management } \\
\end{array}$ \\
\hline Playing the power game & - $\quad$ Employing power tactics responsibly and effectively \\
\hline Working together in interpersonal relationships & - Interpersonal communication \\
\hline
\end{tabular}


Table 3 continued

\begin{tabular}{|c|c|}
\hline Conflict & $\begin{array}{ll}\text { - } & \text { Conflict management } \\
\text { - } & \text { Negotiating effectively } \\
\text { - } & \text { Effective inter-group relations }\end{array}$ \\
\hline When the going gets tough the tough get going & $\begin{array}{ll}- & \text { Motivation theory } \\
\text { - } & \text { Developing a motivating climate in an organisation }\end{array}$ \\
\hline Human resource management: developing manpower & $\begin{array}{ll} & \text { Human resource development and training } \\
\text { - } & \text { Performance measurement }\end{array}$ \\
\hline On becoming an effective leader & - $\quad$ Personal development \\
\hline Ethical leadership & $\begin{array}{l}\text { - Implementation of business ethics within organisational } \\
\text { context } \\
\text { - } \quad \text { Dealing with stress levels }\end{array}$ \\
\hline On becoming an effective leader & $\begin{array}{l}\text { - How the technology can assist leaders to become more } \\
\text { effective }\end{array}$ \\
\hline Revisiting my career & $\begin{array}{l}\text { - The ability to interpret changes in the organisation and adapt } \\
\text { those to a career path }\end{array}$ \\
\hline Diversity in the organisation & - $\quad$ Diversity management \\
\hline Developmental model of leadership & Developing macro-vision for leadership \\
\hline Cultural change & - $\quad$ Dealing with cultural change \\
\hline The financial system and the interest rate prediction & $\begin{array}{l}\text { - Understanding the financial system and the financial } \\
\text { instruments in the financial sector } \\
\text { - Assess and identify the role players in the various markets } \\
\text { within the South African financial system }\end{array}$ \\
\hline International finance & - $\quad$ Understanding the foreign exchange market \\
\hline How to think and reason in macro-economics & $\begin{array}{l}\text { - Understanding macro-economics and its influence on the } \\
\text { organisation }\end{array}$ \\
\hline The law as a regulatory framework for management & $\begin{array}{l}\text { - Understand the nature of the South African legal system and } \\
\text { its application in a business environment }\end{array}$ \\
\hline
\end{tabular}

\section{Relationship between FNB leadership competencies and the BML programme outcomes}

In order to establish whether the BML has addressed the development of leadership competencies at FNB, benchmarking was conducted to establish the links between competencies utilised by First National Bank (South Africa) and the BML programme. Some of the similarities are reflected in the table below. The list is not exhaustive and was not an attempt to accommodate all similarities, but merely an effort to establish a meaningful link between a selection of FNB leadership competencies and BML outcomes.

\begin{tabular}{|c|c|c|}
\hline \multicolumn{3}{|c|}{ Table 4: Relationship between FNB and BML leadership competencies } \\
\hline FNB Competencies & Behaviour & BML Competencies \\
\hline Communication & $\begin{array}{l}\text { Presents ideas convincingly } \\
\text { Facilitates effective communication }\end{array}$ & Interpersonal communication \\
\hline Passion for excellence & $\begin{array}{l}\text { Drives a passion for excellence } \\
\text { (eg. Service, sales excellence) }\end{array}$ & $\begin{array}{l}\text { Act proactively } \\
\text { Begin with the end in mind } \\
\text { Seek first to understand and then to be } \\
\text { understood } \\
\text { Manage differences effectively } \\
\text { Sharpen the saw }\end{array}$ \\
\hline Performance management & $\begin{array}{l}\text { Takes ownership of own performance } \\
\text { Manages others' performance } \\
\text { Clarifies performance expectations with } \\
\text { direct reports }\end{array}$ & Performance measurement \\
\hline $\begin{array}{l}\text { Teamwork and cooperation; } \\
\text { and team development }\end{array}$ & $\begin{array}{l}\text { Promotes a culture of teamwork } \\
\text { Establishes a culture of continuous learning } \\
\text { and development (growth) of team members }\end{array}$ & Human resource development and training \\
\hline
\end{tabular}


Table 4 continued

\begin{tabular}{|c|c|c|}
\hline Impact and influence & $\begin{array}{l}\text { Effectively influences others to reach } \\
\text { agreement between parties and gain win- } \\
\text { win solutions }\end{array}$ & $\begin{array}{l}\text { Employing power tactics responsibly and } \\
\text { effectively } \\
\text { Think win/win }\end{array}$ \\
\hline Decision-making & Participative decision-making & The decision-making process \\
\hline $\begin{array}{l}\text { Customer relationship } \\
\text { management }\end{array}$ & Drives customer relationship management & $\begin{array}{l}\text { Cultivating strong customer relationships } \\
\text { Understanding the competition }\end{array}$ \\
\hline Financial management & $\begin{array}{l}\text { Drives financial performance of department } \\
\text { / branch }\end{array}$ & $\begin{array}{l}\text { Understanding the financial system and the } \\
\text { financial instruments in the financial sector } \\
\text { Assess and identify the role players in the } \\
\text { various markets within the South African } \\
\text { financial system }\end{array}$ \\
\hline Coaching & Coaches team on achieving key result areas & $\begin{array}{l}\text { The role motivation plays in effective } \\
\text { management through applying various } \\
\text { motivational approaches } \\
\text { The control process as important } \\
\text { management task }\end{array}$ \\
\hline Change management & $\begin{array}{l}\text { Drives the effective implementation of } \\
\text { change initiatives }\end{array}$ & Ability to manage change \\
\hline Conflict management & $\begin{array}{l}\text { Facilitates the resolution of conflict } \\
\text { situations in the team }\end{array}$ & $\begin{array}{l}\text { Conflict management } \\
\text { Negotiating effectively } \\
\text { Effective inter-group relations } \\
\text { Problem solving and effective time } \\
\text { management }\end{array}$ \\
\hline Business acumen & $\begin{array}{l}\text { Understands the business of the } \\
\text { organisation } \\
\text { Understands the local business environment }\end{array}$ & $\begin{array}{l}\text { Understanding macro-economics and its } \\
\text { influence on the organisation } \\
\text { Understand the importance of different } \\
\text { organisational settings in terms of strategic } \\
\text { management }\end{array}$ \\
\hline $\begin{array}{l}\text { Risk and compliance } \\
\text { management }\end{array}$ & $\begin{array}{l}\text { Manages risk and compliance } \\
\text { Manages human resource risk to optimise } \\
\text { team performance }\end{array}$ & $\begin{array}{l}\text { Understand the nature of the South African } \\
\text { legal system and its application in a business } \\
\text { environment }\end{array}$ \\
\hline
\end{tabular}

As mentioned, the research was aimed at employees of First National Bank, South Africa who had attended the BML programme. In order to ensure objectivity, their line managers were also invited to participate in the survey. Participants were invited to rate their own understanding and application of managerial leadership behaviour with regard to the researched competencies, at the time of the survey and prior to enrolling on the BML programme. The difference between the two ratings was calculated as the growth in level of competency.

Although students and their line managers differed in their responses as to the level of growth in the various leadership competencies, the overall results of the study concluded that both students and their line managers were of the opinion that the BML programme had indeed contributed significantly to the development of the competencies of leaders at First National Bank.

\section{RESEARCH DESIGN}

In this study a survey was used to collect data. Two similar questionnaires were developed in order to solicit and obtain feedback from students and their line managers, to gather information required to address the aim and objectives of the study. All the students from the various BML intakes that could be traced, including current students, graduates and those who had abandoned the programme, were invited to participate in the survey. The second section of the target audience was made up of the line managers of the students who participated in the survey and who chose to provide the contact details of their line managers.

A questionnaire was sent electronically to 217 students and graduates. Responses were received from 87 individuals, which translate into a response rate of $40 \%$. Eighty respondents chose to disclose the details of their line managers and questionnaires were dispatched to all. Responses were received from 17 of those, resulting in a 
response rate of $21 \%$. The survey was made up of two sections. In the first section of the survey participants were requested to provide biographical information such as age, gender and position held, while in the second section students were requested to rate their own understanding and application of managerial leadership behaviour, currently and prior enrolling to the BML programme. In order to obtain an objective perspective on the students' growth as managerial leaders at FNB, line managers were also requested to evaluate students on the same competency behaviours, currently and prior to their enrolment on the programme.

\section{FINDINGS AND DISCUSSION}

Whilst not all competencies utilized by FNB were included in the study, the chosen list was representative of the competency frameworks of most leadership roles. Twelve competencies were researched and analysed. Respondents were informed that they are required to indicate their understanding and application of managerial leadership behaviour currently and prior to commencing their BML studies, by making use of the following 4 point scale, ranging from "Never" to "Always":

$\begin{array}{lll}1 & = & \text { Never } \\ 2 & = & \text { Rarely } \\ 3 & = & \text { Often } \\ 4 & = & \text { Always }\end{array}$

An analysis was done of the "always" responses as indicated by students and line managers and a summary is provided in the table below:

\begin{tabular}{|c|c|c|c|c|c|c|c|}
\hline \multicolumn{8}{|c|}{ Table 5: Summary of findings } \\
\hline & \multirow[b]{2}{*}{ Competency } & \multicolumn{3}{|c|}{ Students } & \multicolumn{3}{|c|}{ Line Managers } \\
\hline & & Prior & Presently & Growth & Prior & Presently & Growth \\
\hline 1 & Communication & $11 \%$ & $72 \%$ & $61 \%$ & $15 \%$ & $40 \%$ & $25 \%$ \\
\hline 2 & Passion for excellence & $32 \%$ & $76 \%$ & $44 \%$ & $40 \%$ & $60 \%$ & $20 \%$ \\
\hline 3 & Performance management & $10 \%$ & $37 \%$ & $27 \%$ & $30 \%$ & $50 \%$ & $20 \%$ \\
\hline 4 & Promote culture of teamwork & $13 \%$ & $48 \%$ & $35 \%$ & $25 \%$ & $45 \%$ & $20 \%$ \\
\hline 5 & Team development & $16 \%$ & $69 \%$ & $53 \%$ & $15 \%$ & $40 \%$ & $25 \%$ \\
\hline 6 & Impact and influence & $13 \%$ & $53 \%$ & $40 \%$ & $20 \%$ & $45 \%$ & $25 \%$ \\
\hline 7 & Decision-making & $8 \%$ & $66 \%$ & $58 \%$ & $25 \%$ & $35 \%$ & $10 \%$ \\
\hline 8 & Customer relationship management & $52 \%$ & $86 \%$ & $34 \%$ & $40 \%$ & $50 \%$ & $10 \%$ \\
\hline 9 & Business and financial acumen & $16 \%$ & $53 \%$ & $37 \%$ & $25 \%$ & $35 \%$ & $10 \%$ \\
\hline 10 & Coaching & $17 \%$ & $51 \%$ & $34 \%$ & $20 \%$ & $50 \%$ & $30 \%$ \\
\hline 11 & Change management & $11 \%$ & $55 \%$ & $44 \%$ & $30 \%$ & $50 \%$ & $20 \%$ \\
\hline 12 & Conflict management & $11 \%$ & $53 \%$ & $42 \%$ & $20 \%$ & $20 \%$ & $0 \%$ \\
\hline
\end{tabular}

The analysis of the results showed that improved behaviour occurred in all the competencies. The following is an analysis of the five competencies that stand out:

\section{Communication}

Respondents were requested to rate the following behaviour:

"How often do you practice two-way communication efficiently, by clarifying the role and function of all team members, communicating clearly to individuals and teams what is expected of them and adapting your communication style to suit the requirements of the receiver?"

Students indicated a phenomenal improvement of $61 \%$ in their competency behaviour. 


\section{Passion for excellence}

The analysis revealed that BML students have grown by leaps and bounds when it comes to this competency. $76 \%$ of the respondents indicated that currently they "always" display the desired behaviour, compared to $32 \%$ prior to BML. Line managers are in agreement and from their perspective $60 \%$ of students display "always" behaviour when asked the question:

"How often do you drive a passion for excellence in sales, service and other organisational key performance areas?"

\section{Performance management}

This competency shows the lowest scores and the least improvement in required behaviour. It forms part of the competency frameworks of all leadership roles and is therefore seen as a basic requirement for all managerial roles. The required behaviour which was evaluated was as follows:

"How often do you utilise the performance management system to enhance the performance of subordinates and successfully link performance objectives with the strategy of the business unit?".

$10 \%$ of respondents indicated that they displayed "always" behaviour prior to BML, with an improvement of $27 \%$ in current behaviour. When compared to all other competencies, this result accounts for the lowest improvement in behaviour. This was a matter of concern for the researcher, but upon further investigation it was found that judging from the job role of the respondents who reported little improvement in behaviour, there is a possibility that they have no direct reports whose performance would need to be managed. The question referred only to the performance of subordinates and did not solicit a response in terms of management of the respondents' own performance.

\section{Decision-making}

The question posed was as follows:

"How often do you promote a participative decision-making process, which takes into account the contribution of team members?"

Extraordinary growth was evident in this leadership competency, where behaviour improved by $58 \%$. This is significant, taking into account that only $8 \%$ of respondents indicated that they "always" displayed the required behaviour prior to BML, compared to $66 \%$ after BML. While students indicated an improvement in behaviour of $58 \%$, their line managers are of the opinion that there is only $10 \%$ growth in the required behaviour.

\section{Coaching}

This is the competency where students and line managers are mostly in agreement. Students indicated an improvement of $34 \%$ and line managers a similar growth of $30 \%$. The question posed was as follows:

"How often do you coach team members on achieving key result areas?"

\section{Conflict management} following:

The same can be said for this competency, where respondents were asked to rate themselves on the

"How often do you evaluate the feasibility of alternative dispute resolution mechanisms and effectively facilitate the resolution of conflict situations in your team /department? 
Students reported a growth of $42 \%$ and line managers indicated that there was no improvement in this competency behaviour. It is further noticeable that according to line managers only $20 \%$ of students display "always" behaviour, prior to BML and presently. The contrast in this analysis is that while student respondents indicated that they are competent in the competencies of decision-making and conflict management, their line managers do not seem to share the same sentiments.

\section{Open question}

In addition to the questions posed to the respondents to assess the growth in their competency behaviour prior to BML and currently, the following question was posed at the end of the questionnaire in order to solicit additional information pertaining to how the students experienced the BML programme as a leadership development programme:

"What value did BML add to your growth and development as a person and as a managerial leader? Your comments on the BML programme will be appreciated."

The majority of respondents answered this open question and provided comprehensive and overwhelmingly positive feedback regarding their BML experience. The researcher found it extremely challenging to select specific responses to be quoted in this paper, as each comment is relevant and adds value. The following is an extract from one of the most compelling comments received from respondents:

"I did not study a degree prior to joining FNB and as such was only able to rely on "on the job" training / exposure in my decision-making. Whilst I was lucky to be exposed to great managers and learnt a great deal, I never had the opportunity to match my experiential learning with academic theories. I believe it is the combination of the two which allows me to tackle any problem I am faced with. In addition to this, the ability to learn while working may have some disadvantages such as work/life balance and additional stress, but this is far outweighed by the opportunity to learn something in class and then put it into practice the next day at work. It is not like school where you constantly wonder why you need to know this element of that calculation, it is instant gratification of converting theory into practice. So, to answer the question, I have developed quickly throughout the 4 year course and received more than one promotion since the beginning of BML. While the course does not guarantee any growth, development, promotion or salary increase, it certainly gives you a ticket to the game."

\section{CONCLUSION}

The primary purpose of this paper was to explore what contribution the Bachelor in Management and Leadership degree (offered by the University of the Free State in South Africa) has made to the development of leaders at First National Bank, South Africa. The question that was posed was whether the leadership competencies that are required by managerial leaders of financial institutions can be acquired through leadership development programmes that are specifically designed for adult learners, and to what extent such learning interventions contribute to the growth of successful business leaders. Considering the findings of the survey, the researcher concluded that the BML has indeed addressed the researched managerial leadership competencies utilized by FNB and that the programme has contributed significantly to the development of its managerial leaders.

The majority of students indicated that their leadership competency behaviour has improved to a large extent. While their line managers are also of the opinion that the competency behaviour of students has improved, they report a lower degree of growth. Although this was not researched, one of the reasons for this discrepancy may be that line managers feel threatened by the development of the students. It is recommended that in order to enhance the skills acquired from the BML and to further develop and retain BML graduates, further support should be provided in the form of a formal coaching and mentorship programme which should be initiated and implemented by First National Bank, South Africa.

Working in the reality of the South African financial services industry, and facing the unique South African challenges posed by cultural diversity on a daily basis, the resercher can identify with the reality that to be a successful leader in the South African context requires unique and transforming leadership competencies. Although 
programmes such as the BML indeed address and contribute successfully towards the development of leadership competencies, it is predicted that as they become more globally competitive, South African companies will place more emphasis on African leadership competencies in their leadership development programmes in order to address the needs of their particular society.

\section{AUTHOR INFORMATION}

Sylvie Botha holds a BML (Bachelor in Management and Leadership) degree from the University of the Free State. Currently she is an Associate Branch Manager of the Witbank branch of First National Bank in South Africa. As Associate, she leads a banking operation with a medium degree of difficulty that contributes a significant percentage to First National Bank's profitability. Her responsibilities include the management of a fully fledged merchant store front branch that offers a wide range of products and services.

Madaleen Claassens holds a Masters Degree in Career Guidance and a Ph.D in Psycho Pedagogics from the University of Pretoria. Currently she is an independent consultant who works in the field of competency assessment and leadership development. She is also a contracted lecturer at the School of Management at the University of the Free State.

\section{REFERENCES}

1. Booysen, L. \& Beaty, D. 1997. "Linking transformation and change leadership in South Africa: a review of principles and practices". SBL Research Review. Pretoria: University of South Africa, 1(2), pp. 9-18.

2. Khoza, R. 2000. "The need for an Afro-centric approach to management and within it, a South Africanbased management approach". Managing in Health and Social Care, pp. 43-45.

3. Nkomo, S. and Cook, J. in Luiz, J. (ed). 2006. Managing Business in Africa. Cape Town: Oxford University Press.

4. McClelland, D.C. 1973. "Testing for competence rather than intelligence." American Psychologist, 28, pp. $1-14$.

5. Mgidi, L. 2004. "Leadership - in search of an African spirit". Business in Africa, March, pp. 38 -41.

6. Nussbaum, B. 2003. "African Culture and Ubuntu". World Business Academy Perspectives, 17, (1), p.2, viewed on 11 October 2009. http://publications. worldbusiness.org/publications/perspectives

7. Schlebusch, S. \& Roodt, G. 2008. Assessment Centres: Unlocking potential for growth. Randburg: Knowres (Pty) Ltd.

8. Shahin, A. \& Wright, P. 2004. "Leadership in the context of culture: An Egyptian perspective". Leadership \& Organisational Development Journal, 6, pp. 499-511.

9. Ulrich, D., Zenger, J. \& Smallwood, N. 2000. "Building Your Leadership Brand”, Leader to Leaders, Winter, pp. 40-46.

10. Van der Colff, L. 2003. "Leadership Lessons from the African Tree”. Leadership \& Organisasional Development Journal, 41 (3) pp. 257-261. 


\section{NOTES}

